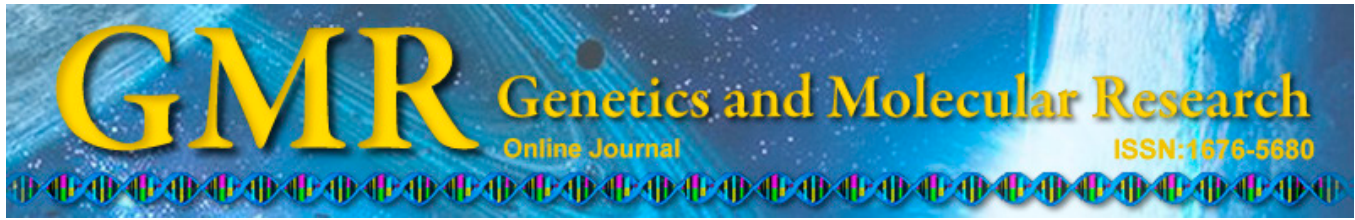

\title{
Development of FQ-PCR method to determine the level of $A D D 1$ expression in fatty and lean pigs
}

\author{
J.X. Cui ${ }^{1,2}$, W. Chen ${ }^{2}$ and Y.Q. Zeng ${ }^{2}$ \\ ${ }^{1}$ Weifang University of Science and Technology, Shouguang, Shandong, China \\ ${ }^{2}$ College of Animal Science and Technology, Shandong Agricultural University, \\ Tai'an, Shandong, China \\ Corresponding author: Y.Q. Zeng \\ E-mail: yqzeng@sdau.edu.cn
}

Genet. Mol. Res. 14 (4): 13924-13931 (2015)

Received January 8, 2015

Accepted May 18, 2015

Published October 29, 2015

DOI http://dx.doi.org/10.4238/2015.October.29.13

\begin{abstract}
To determine how adipocyte determination and differentiation factor 1 ( $A D D 1)$, a gene involved in the determination of pork quality, is regulated in Laiwu and Large pigs, we used TaqMan fluorescence quantitative real-time polymerase chain reaction (FQPCR) to detect differential expression in the longissimus muscle of Laiwu (fatty) and Large White (lean) pigs. In this study, the ADD1 and GAPDH cDNA sequences were cloned using a T-A cloning assay, and the clone sequences were consistent with those deposited in GenBank. Thus, the target fragment was successfully recombined into the vector, and its integrity was maintained. The standard curve and regression equation were established through the optimized FQPCR protocol. The standard curve of porcine ADD1 and GAPDH cDNA was determined, and its linear range extension could reach seven orders of magnitudes. The results showed that this method was used to quantify $A D D 1$ expression in the longissimus muscle of two breeds of pig, and was found to be accurate, sensitive, and convenient. These
\end{abstract}


results provide information regarding porcine $A D D 1 \mathrm{mRNA}$ expression and the mechanism of adipocyte differentiation, and this study could help in the effort to meet the demands of consumers interested in the maintenance of health and prevention of obesity. Furthermore, it could lead to new approaches in the prevention and clinical treatment of this disease.

Key words: Pig; ADD1; FQ-PCR; TaqMan fluorogenic probe

\section{INTRODUCTION}

Adipocyte determination and differentiation factor 1 (ADD1) is a transcription factor that is involved in adipocyte differentiation (Briggs et al., 1993; Yokoyama et al., 1993; Gerbens et al., 2000; Gardan et al., 2006). Previous research has shown that ADD1 is predominantly expressed in adipose tissue and the liver (Tontonoz et al., 1993; Kim and Spiegelman, 1996; Shimano et al., 1997; Kouba et al., 1999), and that ADD1 mRNA expression is associated with adipocyte differentiation in pig (Hausman and Poulos, 2004; Li et al., 2006; Chen et al., 2008; Yue et al., 2010). Furthermore, ADD1 regulates glucose and lipid metabolism in myocytes (Gosmain et al., 2004; Guillet-Deniau et al., 2002, 2004; Hausman et al., 2009). In humans, polymorphisms in the $A D D 1$ gene are associated with obesity and type II diabetes (Eberlé et al., 2004). Overall, ADD1 plays a central role in adiposeness and fat deposition. Therefore, it is necessary to establish a method that can be used to effectively quantify the amount of ADD1 mRNA. Thus, this study was designed to provide plasmid standards for fluorescence quantitative real-time polymerase chain reaction (FQ-PCR) of porcine ADD1 mRNA, and to establish an accurate and convenient method for its detection.

The Laiwu pig is an indigenous Chinese breed, and has better meat quality, particularly higher intramuscular fat (IMF) content, than exotic pigs (Yen et al., 1991; Kinyamu and Ewan, 1994). The IMF content is positively correlated with meat tenderness, juiciness, and taste of pig meat (Zeng et al., 2005; Hu et al., 2008; Lu et al., 2008; Cannata et al., 2010), and is a major determinant that affects sensory meat quality. The improvement and detection of intramuscular fat content are objectives of modern pig-breeding programs, and they would meet the demands of the consumers who wish to maintain health and prevent obesity. Laiwu pigs may be a good model to investigate the mechanism of fat deposition owing to their high IMF content (Chen et al., 2013).

\section{MATERIAL AND METHODS}

\section{Animals and primers}

The experimental protocols were conducted in compliance with Chinese guidelines for human care and use of animals in research. This experiment involved Laiwu pigs $(\mathrm{N}=$ 30) and Large White pigs $(\mathrm{N}=30)$, which were managed in groups at the Laiwu pig-breeding farm. The diet was formulated to meet the nutrient requirement of the pigs (NRC, 1998). Samples were collected from the longissimus muscle, and a portion of the muscle tissue was used to determine the IMF content. Other samples were stored at $-80^{\circ} \mathrm{C}$.

The primers and probes were designed according to the published mRNA sequences 
of porcine $A D D 1$ (NM_214157) and GAPDH (DQ17812) deposited in GenBank. The ubiquitously expressed gene $\bar{G} A P D H$ was used as an endogenous reference to determine the mRNA profiles of target genes (Table 1) (Erkens et al., 2006). Primer specificity was tested by searching for homologous DNA sequences within GenBank by using NCBI BLAST. The internal oligonucleotide probe was labeled with the fluorescent dyes FAM on the 5'-end and eclipse on the 3'-end, which were custom-synthesized by TaKaRa (Dalian, China). All FQ-PCR assays were carried out on a Stratagene Mx3000P device (Stratagene, Santa Clara, CA, USA).

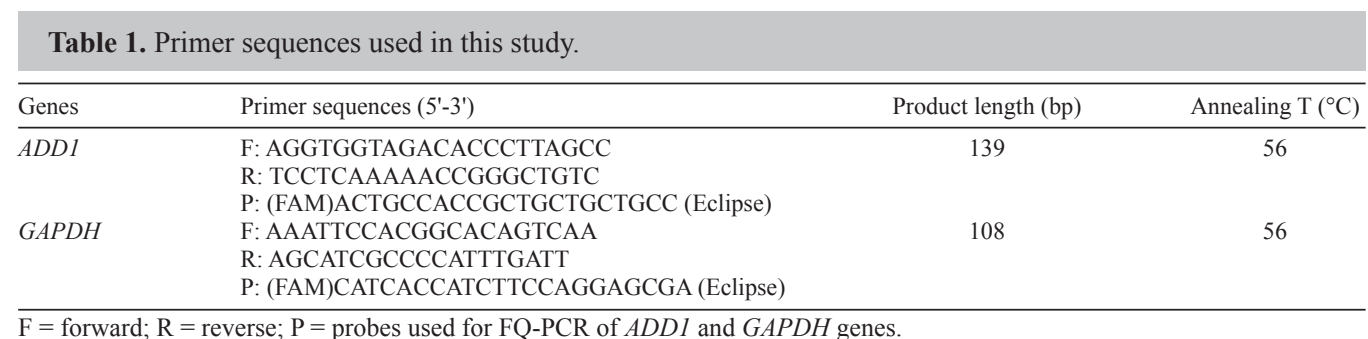

\section{IMF content and backfat thickness (BFT) measurements}

The IMF content of the research pigs was chemically quantified following ISO, 14431973. The method involved the direct Soxhlet extraction of fat by a solvent (AOAC, 2000). To measure the BFT, the thickness of subcutaneous fat between the sixth and seventh thoracic vertebra was measured with Vernier calipers.

\section{RNA extraction and cDNA synthesis}

Total RNA was extracted from the longissimus muscle of Laiwu (fatty) and Large White (lean) pigs using TRIzol reagent (Invitrogen, San Diego, CA, USA), according to the manufacturer protocol (Cui et al., 2011).

\section{Establishment of standard curve}

pMD18-T vector plasmid DNA was used to optimize the real-time FQ-PCR assay in terms of primer and probe concentrations, and annealing and extension temperatures. PCR was performed using a $25-\mu \mathrm{L}$ reaction mix and the program included an initial denaturation step of $94^{\circ} \mathrm{C}$ for $2 \mathrm{~min}$, followed by 40 cycles of $94^{\circ} \mathrm{C}$ for $20 \mathrm{~s}, 56^{\circ} \mathrm{C}$ for $15 \mathrm{~s}, 68^{\circ} \mathrm{C}$ for $60 \mathrm{~s}$, and an additional extension period at $72^{\circ} \mathrm{C}$ for $3 \mathrm{~min}$. The standard curve and standard equation were established using the threshold cycle $(\mathrm{Ct})$ and the original copy numbers of $A D D 1$ and $G A P D H$ in the plasmid DNA templates.

\section{Statistical analysis}

Data were statistically analyzed using the SAS software (SAS Institute, Cary, NC, USA). Gene expression in porcine tissues was analyzed by bivariate correlation using repeated measures. Correlation analyses of $A D D 1$ mRNA expression and meat quality were performed using the PROC CORR procedure of SAS 8.1. The results are reported as means \pm standard 
error of the mean (SE). Significant and highly significant differences were set at $\mathrm{P}<0.05$ and $\mathrm{P}<0.01$, respectively.

\section{RESULTS}

\section{IMF content and BFT}

IMF content and BFT were determined in 60 pigs. The average IMF content of Laiwu was significantly higher than that of Large White. The results indicate that the IMF content was significantly different among breeds $(\mathrm{P}<0.01)$. With regard to BFT, Laiwu was significantly thicker than Large White $(\mathrm{P}<0.01)$. Table 2 shows the average IMF content and BFT of the two breeds of pig.

Table 2. Average intramuscular fat content and backfat in pigs.
\begin{tabular}{lrr}
\hline & \multicolumn{1}{c}{ Laiwu } & Large White \\
\hline Intramuscular fat (\%) & $12.78 \pm 1.02$ & $1.15 \pm 0.07$ \\
Backfat thickness (cm) & $3.25 \pm 0.34$ & $1.55 \pm 0.60$ \\
\hline
\end{tabular}

Data are reported as means $\pm \mathrm{SE}$.

\section{PCR amplification and sequencing analysis}

Identification of PCR amplicons and appraisal of double-restriction enzyme digestion by EcoRI and HindIII is shown in Figure 1. The GenBank BLAST tool was used to align cDNA sequences; the cDNA sequence of the clone was consistent with the ADD1 and GAPDH cDNA sequences deposited in GenBank (Figure 2). Thus, the target fragment was successfully recombined into the vector, and its integrity was maintained.

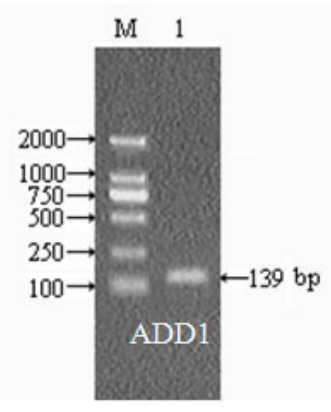

A1

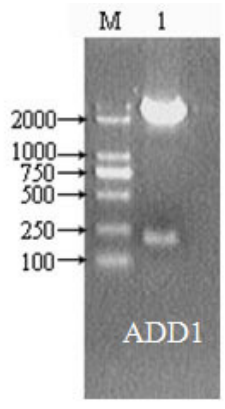

A2

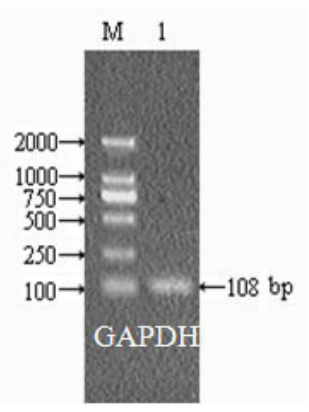

B1

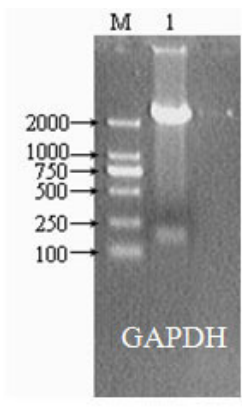

B2

Figure 1. ADD1 and GAPDH PCR amplification identification and double-enzyme cut appraisal. Lane $M=$ molecular marker; lane 1 in $\mathrm{A} 1=\mathrm{PCR}$ product of the $A D D 1$ gene; lane 1 in $\mathrm{A} 2=$ recombinant plasmid-contained $A D D 1$ gene digested by EcoRI and HindIII; lane 1 in B1 = PCR product of the GAPDH gene; lane 1 in $\mathrm{B} 2=$ recombinant plasmid-contained GAPDH gene digested by EcoRI and HindIII.

\section{Establishment of standard curve of ADD1 and GAPDH}

The standard curve of porcine ADD1 and GAPDH cDNA was determined. The re- 
gression equations were: $\mathrm{y}=-3.395 \mathrm{x}+8.14$ and $\mathrm{y}=-3.327 \mathrm{x}+8.03(\mathrm{y}, \mathrm{Ct}$; $\mathrm{x}$, logarithm of template copies), and its linear range extension could reach seven orders of magnitudes, respectively. The $\mathrm{Ct}$ values related to the template copies when the concentration of the original recombinant plasmids ranged from $1 \times 10^{4}$ to $1 \times 10^{10}$ copies $\left(\mathrm{R}^{2}=0.995\right)$.

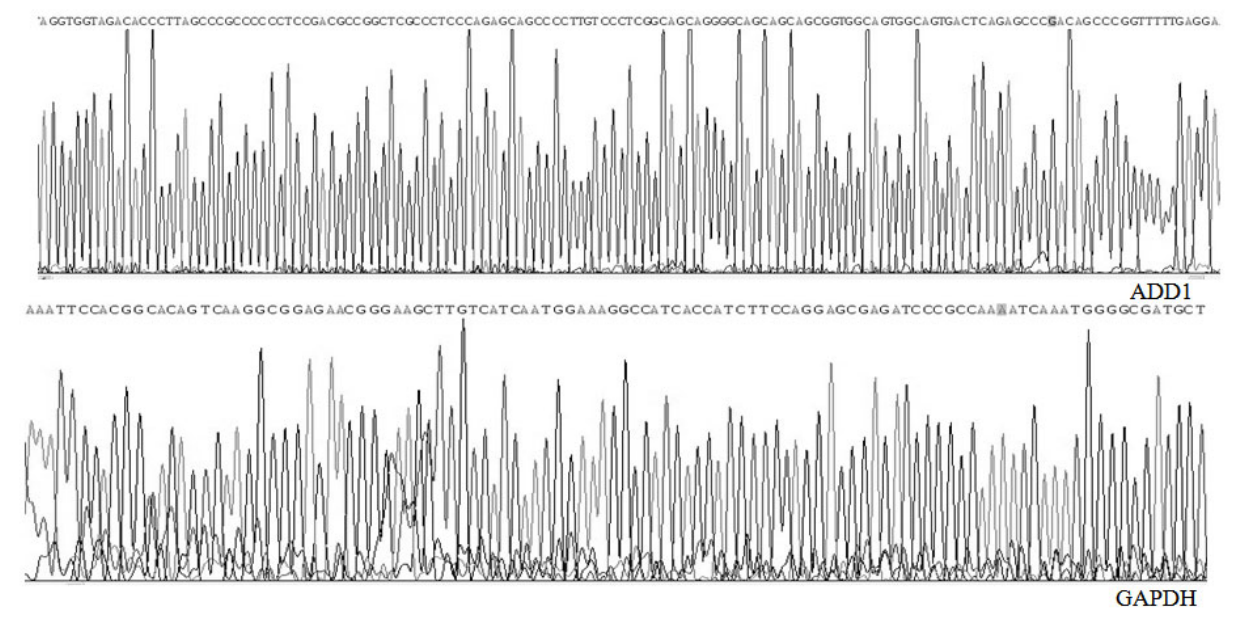

Figure 2. cDNA sequence of ADD1 and GAPDH.

\section{ADD1 mRNA expression level in pig}

As shown in Figure 3, the expression of $A D D 1$ in the longissimus dorsi of Laiwu pigs was consistent when detected by the mRNA probe method or the dye method. The results show that the two methods did not generate significantly different results $(\mathrm{P}>0.05)$. This method of quantifying pig gene mRNA expression is precise and sensitive.

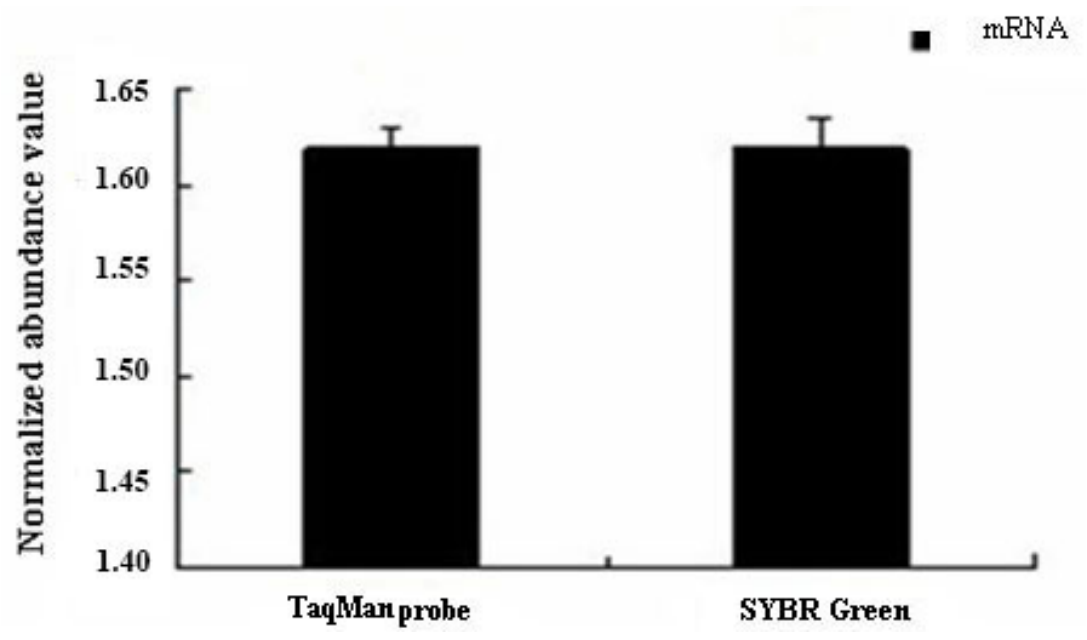

Figure 3. Comparison of two methods for detecting ADD1 expression. 


\section{ADD1 mRNA expression correlated with IMF content and BFT}

The results of the correlation analysis between ADD1 mRNA expression and IMF content and BFT are listed in Table 3. In Laiwu pigs, ADD1 mRNA was expressed at the highest level in adipose tissue, and the expression was significantly different between fat and muscle tissue $(\mathrm{P}<0.05)$. ADD1 mRNA expression in muscle was positively correlated with the IMF $(\mathrm{P}<0.05)$.

There was no correlation between ADD1 mRNA expression in backfat and in muscle. A significant positive correlation was observed between ADD1 mRNA $(\mathrm{P}<0.05)$ and IMF content in fatty pig, and there was no obvious correlation between gene expression and BFT (P > 0.05). With regard to BFT, Laiwu was significantly thicker than Large White, and IMF was significantly different.

Table 3. Correlational analysis between IMF content, BFT, and mRNA expression of ADD1 in Laiwu pig.

\begin{tabular}{lllc}
\hline Gene & Tissues & IMF & BFT \\
\hline ADD1 & Backfat & 0.3762 & 0.0523 \\
& Muscle & $0.6574^{*}$ & 0.3258 \\
\hline
\end{tabular}

$* \mathrm{P}<0.05$.

\section{DISCUSSION}

Methods used to quantify mRNA levels have been reported previously by several researchers (Ranganathan et al., 1995; Livak and Schmittgen, 2001; Gao et al., 2004). FQ-PCR is a technique that has emerged in recent years, and is considered to have high sensitivity and wide dynamic linear range extension (Alkan et al., 2006).

The TaqMan FQ-PCR assay uses probe technology that employs the 5'-3'-nuclease activity of an enzyme, the most commonly used being Taq polymerase. There was a positive relationship between the intensity of the fluorescent signal and the combination of special fragments according to the probes (Bustin, 2000). The number of cycles correlated with the original template number. Accordingly, the original concentration of samples could be calculated using the Ct values by the regression equation (Heid et al., 1996; Yang and Chen, 2002).

In this study, the TaqMan FQ-PCR assay was employed to quantify the level of porcine ADD1 mRNA expression. ADD1 cDNA was cloned using a T-A cloning assay because of the instability of ADD1 mRNA. The effectiveness of the primers and probe was determined by sequencing and alignment. The standard curve and regression equation were established through the optimized FQ-PCR protocol. The samples used for absolute quantification were reversetranscribed to produce first-strand cDNA, and were then amplified by FQ-PCR with standards.

In conclusion, this method could be used to quantify ADD1 expression in fatty and lean pig breeds, and it is rapid, sensitive, and accurate. Establishing this method will aid our understanding of adipocyte differentiation by clarifying that the functions of IMF and BFT are regulated by different mechanisms. The study of this relationship, and consideration of the molecular aspects of the causes of human obesity, could lead to new approaches in the prevention and clinical treatment of this disease. 


\section{Conflicts of interest}

The authors declare no conflict of interest.

\section{ACKNOWLEDGMENTS}

Research supported by the National Natural Science Foundation of China (\#31401055), the Shandong Province Agricultural Animal Breeding Project of China (\#2013LZ02-015), the Shandong Province Modern Pig Technology and Industry System Project (\#SDAIT-06-022-03), the Shandong Province Weifang City Science and Technology Bureau Project of China (\#201301153), and the Shandong Province Weifang University of Science and Technology Project of China (\#W13K003).

\section{REFERENCES}

Alkan N, Gadkar V, Yarden O and Kapulnik Y (2006). Analysis of quantitative interactions between two species of arbuscular mycorrhizal fungi, Glomus mosseae and G. intraradices, by real-time PCR. Appl. Environ. Microbiol. 72: 4192-4199.

Briggs MR, Yokoyama C, Wang X, Brown MS, et al. (1993). Nuclear protein that binds sterol regulatory element of low density lipoprotein receptor promoter I. Identification of the protein and delineation of its target nucleotide sequence. J. Biol. Chem. 268: 14490-14496.

Bustin SA (2000). Absolute quantification of mRNA using real-time reverse transcription polymerase chain reaction assays. Mol. Endocrinol. 25: 169-193.

Cannata S, Engle TE, Moeller SJ, Zerby HN, et al. (2010). Effect of visual marbling on sensory properties and quality traits of pork loin. Meat Sci. 85: 428-434.

Chen J, Yang XJ, Xia DJ, Chen J, et al. (2008). Sterol regulatory element binding transcription factor 1 expression and genetic polymorphism significantly affect intramuscular fat deposition in the longissimus muscle of Erhualian and Sutai pigs. J. Anim. Sci. 86: 57-63.

Chen QM, Zeng YQ, Wang H, Yang L, et al. (2013). Molecular characterization and expression analysis of NDUFS4 gene in m. longissimus dorsi of Laiwu Black (Sus scrofa). Mol. Biol. Rep. 40: 1599-1608.

Cui JX, Zeng YQ, Wang H, Chen W, et al. (2011). The effects of DGAT1 and DGAT2 mRNA expression on fat deposition in fatty and lean breeds of pig. Livest. Sci. 140: 292-296.

Eberlé D, Clément K, Meyre D, Sahbatou M, et al. (2004). SREBF-1 gene polymorphisms are associated with obesity and type 2 diabetes in French obese and diabetic cohorts. Diabetes 53: 2153-2157.

Erkens T, Van Poucke M, Vandesompele J, Goossens K, et al. (2006). Development of a new set of reference genes for normalization of real-time RT-PCR data of porcine backfat and longissimus dorsi muscle, and evaluation with PPARGC/A. BMC Biotechnol. 6: 41-48.

Gao QX, Li J, Liu HL, Wang LY, et al. (2004). Comparative study on lipogenic and lipolytic gene expression in intramuscular fat tissue between growing Erhualian and Large White pigs. Acta Genet. Sin. 31: 1218-1225.

Gardan D, Gondret F and Louveau I (2006). Lipid metabolism and secretory function of porcine intramuscular adipocytes in comparison with subcutaneous and perirenal adipocytes. Am. J. Physiol. Endoc. Metab. 29: E372-E380.

Gerbens F, Koning DJ, Harders FL, Meuwissen TH, et al. (2000). The effect of adipocyte and heart fatty acid-binding protein genes on intramuscular fat and backfat content in Meishan crossbred pigs. J. Anim. Sci. 78: 552-559.

Gosmain Y, Lefai E, Ryser S, Roques M, et al. (2004). Sterol regulatory element-binding protein-1mediates the effect of insulin on hexokinase II gene expression in human muscle cells. Diabetes 53: 321-329.

Guillet-Deniau I, Mieulet V, Le Lay S, Achouri Y, et al. (2002). Sterol regulatory element binding protein-1c expression and action in rat muscles: Insulin-like effects on the control of glycolytic and lipogenic enzymes and UCP3 gene expression. Diabetes 51: 1722-1728.

Guillet-Deniau I, Pichard AL, Kone A, Esnous C, et al. (2004). Glucose induces de novo lipogenesis in rat muscle satellite cells through a sterol-regulatory-element-binding-protein-1c-dependent pathway. J. Cell Sci. 117: 1937-1944.

Hausman GJ and Poulos S (2004). Recruitment and differentiation of intramuscular preadipocytes in stromal-vascular cell cultures derived from neonatal pig semitendinosus muscles. J. Anim. Sci. 82: 429-437.

Hausman GJ, Dodson MV, Ajuwon K, Hausman GJ, et al. (2009). Board Sponsored Invited Review: The biology and 
regulation of preadipocytes and adipocytes in meat animals. J. Anim. Sci. 87: 1218-1246.

Heid CA, Stevens J, Livak KJ and Williams M (1996). Real time quantitative PCR. Genome Res. 6: 986-994.

Hu HM, Wang JY, Zhu RS, Guo JF, et al. (2008). Effect of myosin heavy chain composition of muscles on meat quality in Laiwu pigs and Duroc. Life Sci. 51: 127-132.

Kim JB and Spiegelman BM (1996). ADD1/SREBP1 promotes adipocyte differentiation and gene expression linked to fatty acid metabolism. Genes Dev. 10: 1096-1107.

Kinyamu HK and Ewan RC (1994). Energy and protein metabolism of the Chinese pig. J. Anim. Sci. 72: 2068-2074.

Kouba M, Bonneau M and Noblet J (1999). Relative development of subcutaneous, intermuscular, and kidney fat in growing pigs with different body compositions. J. Anim. Sci. 77: 622-629.

Li CL, Pan YC, Meng H, Wang ZL, et al. (2006). Distributions of Polymorphism of ADD1, MC4R, H-FABP Gene, Associated with IMF and BFT in Three Populations in Pig. Hereditas 28: 159-164.

Livak KJ and Schmittgen TD (2001). Analysis of relative gene expression data using realtime quantitative PCR and the $2 \Delta \Delta \mathrm{C}(\mathrm{T})$ Method. Methods 25: 402-408.

Lu P, Li DF, Yin JD, Zhang LY, et al. (2008). Flavour differences of cooked longissimus muscle from Chinese indigenous pig breeds and hybrid pig breed (Duroc x Landrace x Large White). Food. Chem. 107: 1529-1537.

NRC (1998). Nutrient Requirements of Swine. 10th edn. Nutrient Requirements of Domestic Animals; Washington, D.C.

Ranganathan G, Ong JM, Yukht A, Saghizadeh M, et al. (1995). Tissue-specific expression of human lipoprotein lipase. Effect of the 3'-untranslated region on translation. J. Biol. Chem. 270: 7149-7155.

Shimano H, Horton JD, Shimomura I, Hammer RE, et al. (1997). Isoform 1c of sterol regulatory element binding proteins less active than isoform 1a in livers of transgenic mice and in cultured cells. J. Clin. Invest. 99: 846-854.

Tontonoz P, Kim JB, Graves RA and Spiegelman BM (1993). ADD1: A novel helix-loop-helix transcription factor associated with adipocyte determination and differentiation. Mol. Cell. Biol. 13: 4753-4759.

Yang JR and Chen XD (2002). mRNA quantitative analysis applying Real-time RT-PCR technology. Diagnostics 6: $192-$ 195.

Yen JT, Nienaber JA, Klindt J and Crouse JD (1991). Effect of ractopamine on growth, carcass traits, and fasting heat production of US contemporary crossbred and Chinese Meishan pure- and crossbred pigs. J. Anim. Sci. 69: 48104822.

Yokoyama C, Wang X, Briggs MR, Admon A, et al. (1993). SREBP-1, a basic-helix-loop-helix-leucine zipper protein that controls transcription of the low density lipoprotein receptor gene. Cell 75: 187-197.

Yue T, Fang Q, Yin JD, Li DF, et al. (2010). S-adenosylmethionine stimulates fatty acid metabolism-linked gene expression in porcine muscle satellite cells. Mol. Biol. Rep. 37: 3143-3149.

Zeng YQ, Wang GL, Wei SD, Wang LY, et al. (2005). Studies on carcass and meat quality performance of crossbred pigs with graded proportions of Laiwu Black genes. Hereditas 27: 65-69. 